\title{
Valerii Ivanovich Bovykin, 1928-1998
}

Valerii Ivanovich Bovykin, a professor of economic history at Moscow University and at the Institute of Russian History of the Russian Academy of Sciences, died unexpectedly in Barcelona in September 1998 at the age of 70. During the course of his long and distinguished career, he served as acting director of the Institute of Russian History (then the Institute of History of the USSR) and as a leading figure in the International Economic History Association from the late 1970s through 1998. Bovykin had just completed his work at the 1998 International Economic History Conference meeting in Madrid when he passed away. He had also taken a leading role in the Center for Economic History at Moscow State University, where he headed the bimonthly seminar in conjunction with Leonid Borodkin. Primarily an authority on the economic history of the late tsarist period, Bovykin is remembered by his students and colleagues around the world as a brilliant and productive scholar. He was the author of dozens of scholarly articles and several monographs, including Iz istorii vozniknoveniia pervoi mirovoi voiny (1961); Zarozhdenie finansovogo kapitala v Rossii (1967); and Formirovanie finansovogo kapilala v Rossii (1984). He also edited and contributed to at least a dozen other volumes, including International Banking, 18701914 (1991), with Rondo Cameron and Boris V. Anan'ich and, most recently, Inostrannoe predprinimatel'stvo i zagranichnye investitsii v Rossii (1997). When he died he was at work on a book about French banks in Russia before World War I. Late in life, Bovykin was closely associated with the historical review Byloe edited by S. S. Khizhniakov.

Over the course of his career, Bovykin's scholarly interests embraced foreign relations in the late tsarist period, foreign economic relations, Russian and international banking, and foreign investment in Russia. As a mature scholar Bovykin became interested in comparative economic history, and he dedicated himself to basic research in archives throughout Europe, amassing a great collection of books and documents on the international economic and financial history of the late nineteenth and early twentieth centuries. While much of his published work was set within the traditional confines of Soviet historiography and periodization, Bovykin articulated the conviction that Russian economic experience in the last decades before the Great War was similar in critical ways to that of other European countries. Such an interpretation often met with resistance from his fellow Soviet and post-Soviet historians, who remained convinced of the uniqueness of the Russian case. One of the richest consequences of his scholarly work in later years was the opening of many contacts with foreign scholars in Germany, Belgium, France, Spain, and the United States.

Valerii Ivanovich is remembered with great warmth by his many students as a wise and kind mentor who was keenly interested in their progress and looked out for their wellbeing with gifts, academic contacts, and fatherly advice. Many foreign scholars also benefited from Bovykin's personal generosity on trips to Moscow, and he is mourned in archives and universities throughout Europe, where he had come to be associated with the best qualities of Russian academic life: diligence, intelligence, good humor, and generosity.

Irina A. D'iakonova

Russian Academy of Sciences, Moscow

SUSAN P. MCCAFrRaY

University of North Carolina, Wilmington

May 1999

Slavic Review 58, no. 4 (Winter 1999) 